\title{
O PURO E O HÍBRIDO: O JOGO DE ALTERIDADES NA FORMAÇÃO REPRESENTACIONAL DA UMBANDA BRANCA
}

\author{
Cristina Britto ${ }^{1}$ \\ DOI 10.26512/revistacalundu.v3i1.25240
}

\begin{abstract}
Resumo
Este estudo busca vislumbrar a complexidade da formação identitária do campo umbandista e perceber como, através do jogo de alteridades, ela foi se forjando, sempre tentando vencer a visão estigmatizada das tradições religiosas que a influenciaram. Também se propõe a investigar como alguns discursos essencialistas de representantes do candomblé, kardecismo e catolicismo influenciam a constituição da autoimagem umbandista, sempre balizada ambiguamente pela questão do purismo e da mistura (hibridização). Concebida genericamente por estas tradições como uma seita rudimentar, amoral e baseada na apropriação superficial e ilícita do panteão de outros cultos (demonização dos santos católicos e embranquecimento dos orixás), a Umbanda buscou sair da marginalidade e reivindicar o status de autêntica religião nacional valendo-se de diversas estratégias de construção de uma identidade própria em busca de reconhecimento e difusão social.
\end{abstract}

Palavras-chave: Umbanda pura; Identidade; Pureza.

\section{LO PURO Y LO HÍBRIDO: EL JUEGO DE ALTERIDADES EN LA FORMACIÓN FIGURATIVA DE LA UMBANDA BLANCA}

\section{Resumen}

Este estudio busca comprender la complejidad de la formación de la identitad del campo umbandista y percibir cómo, a través Del juego de alteridades, esta se fue forjando, siempre intentando vencer la visión estigmatizada de las tradiciones religiosas que la influenciaron. También se propone investigar cómo algunos discursos esencialistas de representantes del candomblé, kardecismo y catolicismo influencian la constitución de la autoimagen umbandista, siempre impulsada ambiguamente por la cuestión del purismo y de la mezcla (hibridación). Concebida genéricamente por estas tradiciones como una secta rudimentaria, amoral y basada en la apropiación superficial y ilícita del panteón de otros cultos (demonización de los santos católicos y blanqueamiento de los orichas), la Umbanda busco salir de La marginalidad y reclamar el status de auténtica religión nacional, por medio de diversas estrategias de construcción de una identidad propia en busca de reconocimiento y difusión social.

\footnotetext{
${ }^{1}$ Mestre em História pela Universidade de Brasília (shakti.cristina@gmail.com)
} 
Revista Calundu - Vol.3, N.1, Jan-Jun 2019

Palabras clave: Umbanda Pura; Identidad; Pureza

\title{
Do mito fundador à institucionalização
}

\begin{abstract}
Pureza e impureza criam unidade na experiência. Longe de serem aberrações do projeto central da religião são contribuições positivas para expiação. Através deles os padrões simbólicos são executados e publicamente manifestados (DOUGLAS, 1996, p.13).
\end{abstract}

Fruto de uma tradição híbrida, constituído por elementos de três importantes denominações religiosas difundidas no território nacional (catolicismo, kardecismo e candomblé), o culto umbandista se expressa por seu caráter heterogêneo e popular. Suas primeiras manifestações são de difícil datação, pois ocorreram em momentos distintos nas diferentes regiões do país, sem a representação unívoca de um mito fundador ou de um personagem doutrinário, difusor dos princípios da religião nascente.

No entanto, é ponto pacífico entre os estudiosos da umbanda que suas origens, enquanto culta organizada data do início do século XX e que seus aspectos dogmáticos possuem forte influência do espiritismo kardecista, difundido no Brasil desde a segunda metade do século XIX, sob a orientação da Federação Espírita Brasileira, fundada em 1884.

Definido pelo antropólogo Ordep Serra (1996, p. 13) como um culto "de estilo xamânico, assinalado por forte ecletismo", a Umbanda é alvo de incontáveis narrativas fundadoras que pretendem situar sua gênese de forma vaga e abstrata "em tempos imemoriais e continentes remotos" (GIUMBELLI apud SILVA, 2002, p. 183). Diante das diversas representações descentralizadas que tentam definir o culto, um mito originário da formação do campo umbandista no Rio de Janeiro chama a atenção por sua pretensa objetividade, ancorado numa datação exata e construído com o recurso de uma narrativa fundacional normativa.

Os relatos sobre a experiência mística do médium Zélio Fernandino de Moraes, ocorrida em 1908, impressionam pela riqueza de detalhes e a intenção assumida de constituir e organizar uma nova prática religiosa. Segundo registros expostos em obras litúrgicas como as de Aluízio Fontenelle (1953), Antônio Cavalcanti Bandeira (1961), Jota Alves de Oliveira (1985) e Diamantino Fernandes Trindade (1991), na noite de 15 de novembro de 1908 o jovem Zélio foi levado a uma sessão na sede da Federação 
Espírita de Niterói para tentar acalmar transes mediúnicos agitados e intermitentes. Durante a reunião mediúnica, Zélio levantou-se bruscamente e incorporou o espírito de um índio. Ao solicitar que o espírito se retirasse, por considerá-lo de "baixa vibração", os médiuns que compunham a sessão foram surpreendidos com um questionamento da entidade: porque repeliam "alguém que nem se dignaram ouvir. Seria por causa das origens sociais e da cor? Sou o Caboclo das Sete Encruzilhadas. Para mim, não há caminhos que não possam ser abertos" (GIUMBELLI, Op. Cit., p. 185). Um tumulto generalizado se estabeleceu na sessão. Um dos videntes interpelou a entidade dizendo que via nela restos de trajes sacerdotais. O espírito respondeu:

O que você vê em mim, são restos de uma existência anterior. Fui padre e meu nome era Gabriel Malagrida. Acusado de bruxaria fui sacrificado na fogueira da Inquisição em Lisboa, no ano de 1761. Mas em minha última existência física, Deus concedeu-me o privilégio de nascer como caboclo brasileiro. (TRINDADE, 1991, p. 60)

O espírito então anunciou que vinha em missão especial do "plano superior "e deveria fixar as bases de um novo culto no qual todos os espíritos de pretos-velhos e caboclos deveriam trabalhar em auxílio espiritual da nação brasileira”“. Para cumprir esse propósito, um templo que congregaria a igualdade para todos, encarnados e desencarnados, seria fundado no dia seguinte (16 de novembro de 1908) na residência do médium, às 20 horas. Antes de "subir", o Caboclo pronunciou estas últimas palavras:

Deus, em sua infinita bondade, estabeleceu a morte, o grande nivelador universal. Ricos e pobres, poderosos e humildes, todos se tornariam iguais na morte. Mas vocês, homens preconceituosos, não contentes em estabelecer diferenças entre vivos, procuram levar essas mesmas diferenças além da barreira da morte. Porque não podem nos visitar esses humildes trabalhadores do espaço, se apesar de não haverem sido pessoas socialmente importantes na terra, também trazem importantes mensagens do além? (Op. Cit., p. 61)

As obras litúrgicas relatam que no dia seguinte foi fundada na cidade Neves, interior do estado do Rio, aquela considerada a primeira casa "oficial" de trabalhos espirituais umbandistas do país, a Tenda Nossa Senhora da Piedade. Os relatos da trajetória de Zélio afirmam que, por orientação do Caboclo das Sete Encruzilhadas, entre 1917 e 1918, mais sete tendas foram criadas e indicadas seus dirigentes com o intuito de levar a mensagem da lei de umbanda para todo o país.

Zélio de Moraes também foi um dos articuladores da criação da primeira 
federação umbandista do Brasil de que se tem notícia, a Federação Espírita de Umbanda- FEU, fundada em 1939. Visando principalmente o reconhecimento social do culto, em outubro de 1941, a FEU promoveu o $1^{\circ}$ Congresso Brasileiro de Espiritismo de Umbanda, que lançou definitivamente as bases filosóficas da corrente umbandista denominada por Diana Brown (1985) de "Umbanda Pura", por designar uma modalidade de culto formada a partir de bases doutrinárias calcadas na tradição cristã e kardecista, a despeito do culto a entidades afro-americanas. Patrícia Birman (1983) preferiu adotar a designação "Umbanda Branca", que denota as diversas restrições às práticas africanas consideradas "bárbaras" e "primitivas" para assumir um ideal de culto letrado e civilizacional ${ }^{2}$.

Aqui é importante destacar que a maioria das narrativas sobre a fundação da Umbanda Pura registra que no dia da primeira sessão na Tenda Nossa Senhora da Piedade, o médium Zélio também "recebeu" outra entidade, um negro que atendia pelo nome de Pai Antônio Curador e que teria a função de auxiliar nos trabalhos terapêuticos coordenados pelo Caboclo das Sete Encruzilhadas. O papel deste preto-velho, arquétipo do escravo humilde e conformado, pode ser entendido como a presença da África consentida desde que ocupe um lugar subalterno e "controlado" no ritual. Há ainda referências sobre a manifestação de um guia auxiliar de origem africana, denominado Orixá Malê, cuja principal característica seria a experiência no desmanche de trabalhos de baixa magia. Neste caso, a referência à africanidade continua sendo secundária, pois estaria associada a uma energia mais densa, pesada, utilizada para "fazer o trabalho sujo", ou seja, lidar com o que há de mais "primitivo" e maléfico.

Assim formava-se a tríade da simbologia umbandista que a narrativa fundacional do Caboclo das Sete Encruzilhadas procurou consolidar: índio valente, negro humilde, branco racional. Enquanto os aspectos indígenas e africanos se expressariam nos papéis de entidades trabalhadoras, como guias de orientação e cura, a contribuição da cultura branca seria filosófica: era a influência do colonizador europeu, portador da doutrina "civilizada" e cristã, responsável pela ressignificação das mensagens de Allan Kardec e das crenças do catolicismo popular.

A partir da federalização e do discurso jornalístico- divulgado pelo Jornal de Umbanda, periódico oficial da FEU a partir de 1942 - a mensagem do Caboclo das Sete

\footnotetext{
2 A designação Umbanda Pura, utilizada pela pesquisa, é o termo mais adotado pelos seguidores dos ensinamentos do Caboclo das Sete Encruzilhadas, como uma atribuição de sentido construída pela intelectualidade umbandista. A escolha da denominação também se justifica pela análise da dicotomia entre pureza e impureza religiosa.
} 
Encruzilhadas pôde ser difundida em larga escala e o que era apenas uma narrativa mítica tomou proporções ideológicas, chegando a dialogar com um certo projeto de identidade nacional que se aproxima do que Marilena Chauí (2000) convencionou chamar de período do "caráter nacional".

\section{Identidade e Pureza}

Ao analisar os conteúdos da literatura umbandista divulgada pela FEU pode-se afirmar que o processo de gestação e legitimação da "Umbanda Pura" foi constituído entre os polos da tradição africana (macumba/candomblé) e cristã (kardecismo/catolicismo) estabelecendo um continuum mediúnico que parte da extremidade negra para se adaptar aos ideais e à moralidade branca e positiva. Segundo o sociólogo Cândido Procópio Ferreira de Camargo, o conceito de continuum mediúnico une, por similitudes, "as modalidades intermediárias que se organizam, combinando de incontáveis maneiras as soluções ritualísticas e doutrinárias dos extremos", possibilitando "a fácil mobilidade dos adeptos em meio a estas formas objetivas de culto e doutrina e a configuração do início de uma autoconsciência religiosa" (CAMARGO, 1961, p. 12).

Assim, entidades negras e indígenas que já se manifestavam "informalmente" em médiuns de outras tradições foram identificadas e classificadas dentro de um novo culto que, apesar de ressaltar elementos afro-xamânicos, baseou sua doutrina em princípios cristãos. A despeito da orientação dos intelectuais umbandistas e do movimento federativo para uma identificação progressiva com a polaridade cristã, os rituais de umbanda transitam irregularmente pelas polaridades que balizam sua identidade, longe de seguir um sentido único e homogêneo.

Aos olhos críticos da intelectualidade umbandista, o ritual essencialmente festivo do candomblé foi concebido muitas vezes como símbolo de espetáculo folclórico, luxo excessivo, feitiçaria primitiva, comércio e promiscuidade (apologia à libertinagem e ao homossexualismo). Tais festas contrastam com as concepções doutrinárias da Umbanda Pura cujos rituais são entendidos como uma forma de trabalho, uma "demanda" 3 a ser comprida, uma missão.

\footnotetext{
${ }^{3}$ A origem primordial da palavra é jurídica significando ação judicial, processo ou litígio. Na umbanda a expressão "vencer demanda" é sinônimo da resolução dos mais variados tipos de problemas como um trabalho a ser executado, uma peleja, um combate, uma cura, ou seja, a remoção de qualquer obstáculo que possa "fechar os caminhos" e impedir a felicidade da vida do consulente.
} 
A ausência dos atabaques no ritual da Tenda Nossa Senhora da Piedade e demais casas fundadas pelo Caboclo das Sete Encruzilhadas- nas quais as cerimônias são ritmadas apenas por cânticos e palmas - é extremamente significativa, pois representa o estigma do tambor enquanto instrumento africano por excelência. Todavia, a atração que estes terreiros exerciam sobre muitos fiéis e médium era vista pelos dirigentes de tendas da linha pura como uma ameaça real à vitória sobre as demandas e ao cumprimento da "Lei de Umbanda":

\begin{abstract}
ALERTA contra esta proliferação de "babás e babalaôs" que, por esquinas e vielas, transformavam a nossa Umbanda em cigana corriqueira, enfeitada de colares de louça e vidro, e ao som de tambores e instrumentos bárbaros, vão predispondo mentes instintivas a excitações, geradoras de certas sensações, que o fetichismo embala das selvas africanas aos salões da nossa metrópole ${ }^{4}$.
\end{abstract}

A contraposição entre a natureza festiva do candomblé e a característica laboral exaltada pela Umbanda Pura é elemento que ressalta o ideal dito progressista que permeia os ensinamentos umbandistas. Este ideal é fortemente balizado por uma hierarquia tanto dos médiuns como dos próprios espíritos, classificados segundo o nível de evolução. Neste sentido, é tarefa dos médiuns umbandistas despertar nos espíritos a seriedade e gosto pelo trabalho como caminho de purificação.

São estas práticas, unidas pelo princípio comum do mediunismo e da reencarnação, que interligam as crenças kardecistas, umbandistas e do candomblé. Metaforicamente, a umbanda seria como um pêndulo híbrido que transita irregularmente entre as extremidades "branca" e "negra". Entretanto, é interessante notar que os pólos do continuum são marcados, em sua construção identitária, pelo ideal de pureza. Tanto os intelectuais legitimadores do candomblé como os do kardecismo se apresentam como detentores da pureza, ou seja, representantes de uma tradição em "estado original, uma espécie de reduto cultural preservado das influências deturpadoras de elementos estranhos" (DANTAS, 1988, p. 145). Logo, a umbanda institucionalizada também busca o puro, a noção de religião legítima.

É certo que o significado deste anseio pelo essencialismo varia de um culto para outro, todavia o que os une é o desejo de aceitação social, de assumir o papel de legítimos mantenedores de uma tradição única que instaura a ordem e é detentora da autoridade. Em seu trabalho Pureza e Perigo, Mary Douglas (1996) afirma que no

\footnotetext{
${ }^{4}$ Jornal de Umbanda. № 61, Dezembro de 1955.
} 
campo religioso a ideia de pureza pode ser associada à manutenção do poder e da ordem. Sendo assim, a lógica do puro/impuro reflete uma demarcação de limites, uma maneira de definir "um lugar para si e para os outros no conjunto do esquema de forças simbólicas da sociedade" (DOUGLAS, Op. Cit., p. 143). Segundo esta perspectiva, a Umbanda parece emergir no limiar entre os ideais de pureza nagô e do evolucionismo kardecista (purificação pelo progresso), tentando estabelecer seu lugar ao sol em meio a um jogo de alteridades em que estigmatiza e é estigmatizada.

A relação de interdependência entre estabelecidos e outsiders, conceituada por Norbert Elias, pode ser de grande ajuda para entender este jogo de alteridades. Nesta sociodinâmica da estigmatização deve existir um “equilíbrio instável de poder", ou seja, a capacidade de manter o outsider sob controle deve ser alcançada pela coerência e organização do grupo estabelecido para que haja a "dominação". Garantindo a dispersão e a anomia do grupo subjugado, os estabelecidos exercem o poder de retaliá-lo e censurá-lo. Quando esta situação se inverte e os estabelecidos (que a princípio seriam os portadores de uma virtude superior e carisma grupal distintivo) se enfraquecem, os outsiders reagem e passam à condição de subjugadores, como um constante efeito bumerangue de dominação encontra dominação.

\begin{abstract}
Afixar o rótulo de "valor humano inferior" a outro grupo é uma das armas mais usadas pelos grupos "superiores" nas disputas de poder, como meio de manter sua superioridade social. Nessa situação, o estigma social imposto pelo grupo mais poderoso ao menos poderoso costuma penetrar na autoimagem deste último e, com isso, enfraquecê-lo e desarmá-lo (...). Tão logo diminuem as disparidades de força ou, em outras palavras, a desigualdade do equilíbrio de poder, os antigos grupos outsiders, por sua vez, tendem a retaliar. Apelam para a contra-estigmatização (ELIAS e SCOTSON, 2000, p.24).
\end{abstract}

\title{
A Pureza Nagô: umbanda carioca versus candomblé baiano
}

Segundo Beatriz Góes Dantas (1988), o conceito de pureza nagô foi inicialmente delineado por Nina Rodrigues que defendeu a superioridade da etnia sudanesa de língua iorubá, predominantemente advinda da Costa dos Escravos e da Costa do Ouro (Benin ou antigo Daomé e Nigéria). Os assim denominados nagôs eram concebidos por Nina Rodrigues como uma organização social mais complexa que os sudaneses islamizados (haussás) e os povos de língua banto provenientes de Angola, Congo e Moçambique.

Baseado em um esquema evolucionista, Nina Rodrigues traça uma hierarquia dos povos africanos no Brasil, priorizando os nagôs como detentores de uma língua e 
uma mitologia mais complexa, além da existência de uma estrutura de rito e sacerdócio bem definidas. À pretensa superioridade nagô, contrapunha-se o "atraso" dos negros bantos, em sua maioria radicada no sudeste do país. Esta perspectiva contribuiu para definir a construção de identidades bem distintas e opostas entre os negros do nordeste e do sul. Apresentando o culto nagô como a verdadeira religião africana, Nina Rodrigues instaura uma categoria de análise e relegam as demais práticas à marginalidade, classificadas como fetiche ou magia degenerada.

Como discípulo de Nina Rodrigues, Arthur Ramos reforçou a ideia da supremacia nagô, mas ressaltou seu caráter cultural, deixando de lado a justificativa científico-racial abordada por seu mestre ao afirmar que "a macumba dos negros cariocas é a menos interessante dessas sobrevivências religiosas, tal seu grau de diluição, sua rápida transformação ao contato com a civilização do litoral" (RAMOS, 1971, p. 104).

É interessante notar que a própria palavra "macumba" é utilizada pejorativamente, para distinguir os cultos negros cariocas do reconhecido candomblé baiano. Desta macumba - concebida por Roger Bastide como uma espécie de degradação mágica amoral e individualista de alguns rituais bantos - teria advindo, em parte $^{5}$ a umbanda. À macumba estaria associada à ressignificação da figura de Exu entidade do panteão africano responsável pelas tarefas telúricas e pela comunicação entre os orixás e os homens - que passa a ser concebida como sinônimo de indisciplina e feitiçaria.

$\mathrm{Na}$ percepção de Bastide, a umbanda reorganizou e adaptou a macumba (enquanto deformidade dos valores tradicionais de origem banto) e os cultos indígenas à nova realidade social das camadas médias no princípio do século XX, ou seja, tornou-a mais "civilizada", uma vez que ela "cruza os exus e os caboclos, vale dizer o que resta das religiões africanas com o que resta das religiões índias, e sob o sinal-da-cruz" (BASTIDE, 1989, p. 470). Assim, Bastide descreve a umbanda como uma releitura das crenças "animistas "dos negros bantos e dos indígenas, segundo os conceitos espíritas kardecistas"“.

A dicotomia nagô/banto serviu como aporte para delinear diferenças de representação social entre candomblé e umbanda e localizá-los geograficamente no eixo

\footnotetext{
${ }^{5}$ Em parte, porque ela também descenderia do candomblé de caboclo, uma forma de culto que adapta elementos indígenas da pajelança à estrutura do candomblé. Este culto sincrético afro-ameríndio é visto por Bastide como "superior" à macumba por obedecer a uma estrutura moral e litúrgica.
} 
Salvador/Rio. Segundo os estudos de Beatriz Góis Dantas (Op. Cit.), a exaltação intelectual do candomblé nordestino em detrimento da umbanda sulista é influenciada por fatores históricos que marcam a diferença de inserção social da população negra nestas duas regiões. O fenômeno da imigração estimulou o ideal de branqueamento levado a cabo pelas elites do Sul e do Sudeste na tentativa de construir uma imagem "positiva" do Brasil no exterior.

Desvalorizar a herança africana fazia parte deste programa que, segundo Thomas Skidmore, era um objetivo gestado desde o século XIX pela aristocracia do sudeste interessada no rápido desenvolvimento econômico do país, atrelado diretamente a "resolução" do problema racial (SKIDMORE, 1976). A umbanda, portanto, nasceu em um meio social em que o negro continuava sendo visto como escravo, a despeito da abolição, e sua influência cultural era concebida como um resquício de atraso e barbárie. Cercados por filosofias positivistas, os esforços dos intelectuais umbandistas voltaram-se para busca de outras referências culturais que purificassem o culto, livrando-o da imagem anômica da feitiçaria no intuito de torná-lo uma religião socialmente aceita. Para Dantas, "é através da negação da África que a Umbanda se tornará 'limpa', 'branca', pura”, identificada como uma prática do bem, por caridade e sem cobrança, apta, pois, a ter uma aceitação social mais ampla (DANTAS, 1998, p. 209).

A situação do Nordeste era bem distinta. O contingente de negros na região era infinitamente superior e a possibilidade de ignorar e diluir (embranquecer) este grupo era praticamente inviável. Desta maneira, exaltar a herança africana era um caminho possível para escamotear o preconceito social em face da valorização do exotismo negro, ressaltando os aspectos culturais sem, no entanto, resolver a precariedade de sua condição socioeconômica. Os intelectuais nordestinos estimularam uma espécie de tratamento paternalista como um eficiente mecanismo para inibir a "identidade coletiva e a solidariedade política do negro" que é "polidamente mantido em seu lugar. Reforçase, assim, a difundida e falsa impressão de que no nordeste a situação do negro é mais benigna e as desigualdades sociais entre negros e brancos são menores” (Op. Cit., p. $12)$.

O ideal representativo da pureza nagô nasceu neste cenário que retrata o negro, antes de tudo, como "portador" de uma cultura ancestral exótica e complexa, refletida em suas formas religiosas originais. O candomblé baiano de tradição nagô/Ketu passa a 
ser representado como a mais difundida e preservada destas expressões ao manter a fidelidade aos ritos e à língua iorubá, considerada a mais avançada das sociedades africanas.

A divulgação de estudos acadêmicos que exaltavam os cultos africanos classificando a umbanda como uma degeneração sincrética surtiu efeito nos meios umbandistas que passaram a ressaltar ainda mais o seu caráter nacional e, portanto, mestiço, híbrido, em contraposição ao essencialismo estrangeiro do candomblé. Tais aspectos regionais influenciaram a intelectualidade umbandista e do candomblé e contribuíram para delinear identidades simultaneamente opostas e complementares. A pureza umbandista denota mistura como sinônimo de equilíbrio, igualdade e progresso civilizacional. A pureza do candomblé busca a preservação de rituais baseados nas crenças específicas de uma tradição africana. Neste sentido, o status de religião é perseguido por ambos os cultos, porém com estratégias distintas: a Umbanda tenta domesticar os elementos que considera mágicos enquanto o candomblé exalta tais elementos. Segundo Birman, "Se para uma corrente expressiva da intelectualidade dominante, os cultos afro dignos de respeito eram aqueles que se conservavam “ puros'... [para] a primeira federação umbandista exatamente o oposto era valorizado. Quanto mais se 'embranquecesse' os cultos, mais legítima se tornaria a religião" (BIRMAN, 1985, p. 88).

\section{A Pureza Cristã: Kardecismo e Catolicismo}

Pelo fato de ter sido pronunciado dentro da Federação Espírita de Niterói, o discurso fundante da Umbanda tem obviamente como primeiro e mais atuante interlocutor o pensamento kardecista que, por isso mesmo, pode ser considerado a principal base filosófico-doutrinária do culto umbandista. Por serem as duas mais populares tradições reencarnacionistas difundidas no Brasil e terem se desenvolvido em período de tempo muito próximo, kardecismo e umbanda disputaram muitas vezes os mesmos espaços tentando se constituir como "uma alternativa possível no processo de adaptação das personalidades às exigências da vida urbana” (CARMARGO, Op. Cit., p. 97). Diz-se possível porque não é o caso de se pensar a religiosidade de forma utilitária (como um simples instrumento para a resolução de questões pessoais) ou determinista (influência ideológica de uma classe social), todavia é inegável assinalar que, com o advento do século XX, as tradicionais estruturas religiosas conhecidas no Brasil já não 
correspondiam aos anseios das camadas médias que habitavam as grandes cidades, sedentas por um contato mais próximo e "real" com o sagrado capaz de dar sentido a um cotidiano acelerado e caótico como uma espécie de "ampliação do espaço das explicações mágicas e religiosas na sociedade" (MARTINS, 2005).

O racionalismo do século XIX, marcado pela difusão das ideias positivistas de progresso e desenvolvimento ordenado do mundo como afirmação do saber científico materialista, é resultado de um longo e descontínuo processo de separação entre o conhecimento de base experimental e a metafísica. Neste período, o cientificismo contrapunha abertamente ciência e religiosidade, eliminando Deus enquanto princípio metafísico de explicação da realidade.

É esta veemência antirreligiosa que irá gerar uma onda de espiritualismo eclético, com grande repercussão no meio intelectual artístico europeu, influenciando diretamente a eclosão do movimento romântico, aliado a um sentimento reencarnacionista que se difundiu entre grandes escritores da época como Victor Hugo, Balzac, Shelleye Walt Whitman. "Era o contraponto das ciências ocultas e místicas ao estabelecimento da grande deusa Ciência” (DAMAZIO, 1994, p. 23).

Nos Estados Unidos, denominações como a Igreja Mórmon, os Testemunhas de Jeová, a Igreja de Cristo e o Moderno Espiritualismo das irmãs Fox foram as principais representantes deste movimento eclético e difuso. O caso das irmãs Fox é o que mais interessa a este estudo, pois foi o desencadeador de uma série de investigações sobre o fenômeno mediúnico das "mesas girantes" que precederam a Codificação da Doutrina Espírita kardecista. Tamanha foi a amplitude e difusão das "mesas girantes" que as práticas sofreram intervenção do Santo Ofício em 1856, sendo proibidas sob pena de excomunhão e acusadas de charlatanismo e hipnose. Todavia, esta imposição não impediu que o professor francês Léon Denizard Rivail, a partir do estudo destas e de outras manifestações consideradas "sobrenaturais", tentasse conciliar ciência e religião codificando uma doutrina inspirada pelos espíritos.

Allan Kardec (pseudônimo de origem celta adotado por Leon como referência a uma encarnação passada) organizou um corpo doutrinário selecionando informações ditadas por diversos espíritos, através de um grupo de médiuns, adotando procedimentos científicos de observação e experimentação. O espiritismo kardecista, fundado em 1857 com a publicação do Livro dos Espíritos, reintroduz noções do cristianismo primitivo reavivando a mensagem evangélica sob uma óptica reencarnacionista, a partir de uma 
leitura do neoplatonismo.

É importante ressaltar que a estruturação do kardecismo enquanto manifestação primordialmente religiosa, e não apenas como doutrina filosófico-científica, é uma característica essencial do espiritismo desenvolvido no Brasil. O caráter racional ainda norteia os princípios doutrinários, reforçados pela prática de estudos filosóficos, mas uma característica básica é responsável pelo sucesso e crescimento do kardecismo no Brasil: o tratamento terapêutico, a assistência social e a literatura mediúnica. Estes "atrativos" também são oferecidos pelas tendas de umbanda com a ressalva de que as práticas kardecistas são mais objetivas, rejeitando quaisquer elementos místicos dentro do culto que se desenvolve a partir de uma perspectiva intelectualizada e antirritualística.

A pureza segundo a concepção kardecista está relacionada diretamente à retidão do pensamento e à moralidade. Allan Kardec (2001) ressalta que nenhuma espiritualidade que estimule, mesmo que indiretamente, qualquer ação antiética ou se baseie mais no ritual que na mensagem pode tornar o homem perfeito. A exaltação do espírito - enquanto verdadeira essência da identidade, da inteligência e da vontade do indivíduo - torna a corporeidade da existência terrestre uma condição inferior e, portanto, impura.

Uma das maiores divergências entre kardecistas e umbandistas talvez seja justamente a relação destas denominações com os diversos aspectos da materialidade e sua ligação com o conceito de moralidade, vista como sinônimo de pureza pelos espíritas. A contra argumentação umbandista destaca que a resolução de problemas do mundo material e a busca por todo tipo de cura sempre foram características comuns aos dois cultos, pois "as mesmíssimas criaturas que vão aos centros Espíritas em busca de remédios para os seus males, vão igualmente aos centros de Umbanda "e muitas vezes a ajuda vem "de um 'terreirinho' humilde, onde se pratica a Religião de Umbanda e onde se trabalha em nome de Jesus" 6 .

Nesta disputa percebe-se que as diferenças rituais é que estão em jogo, pois no âmbito doutrinário estas duas tradições são muito próximas. No caso da umbanda, o corpo é visto como um espaço de integração entre o sagrado e o profano, veículo do transe mediúnico expressivo, base de todo oculto. Sulivan Barros (2004) reflete que "é na possessão que todo o edifício umbandista adquire sentido", pois o transe seria "a

\footnotetext{
${ }^{6}$ Jornal de Umbanda. N. 29, Março de 1959.
} 
instância ritual que permite que seu trabalho seja feito, que as divindades colaborem com as necessidades humanas e que sejam recompensadas por isto" (Op. Cit., p. 205). Segundo Muniz Sodré (1999), nas tradições africanas em geral, o corpo tem um papel de destaque na experiência ritualística, concebido dentro de uma visão integrativa que une o indivíduo à comunidade e à natureza, como um microcosmo, um santuário que abriga a energia vital (axé). Nestes grupos, o corpo estaria associado ao simbolismo coletivo e à ação social.

Já o kardecismo tenta desmistificar suas práticas, considerado a umbanda como prática "espiritualista" (reencarnacionista), mas não "espírita" (fiel à codificação kardequiana). Os diversos debates em torno da utilização da terminologia espiritismo expostos na literatura umbandista em geral não chegam a um consenso, mas a maioria das narrativas afirma que a umbanda veio complementar a missão de Kardec, sendo considerada como a Quarta Revelação ${ }^{7}$.

Aqui entra em discussão os lugares de fala: O Espiritismo kardecista se apresenta como uma religião autêntica e pura por ser uma revelação inspirada pelo "Espírito de Verdade", manifestação da própria divindade suprema judaico-cristã, enquanto a Umbanda Pura foi fundada pela mensagem do Caboclo das Sete Encruzilhadas, considerado pelos kardecistas como um mero espírito em evolução. Bourdieu (1992, 1998) lembra que o poder de mediação das palavras, seja ele revolucionário ou conservador, está diretamente relacionado à credibilidade do narrador. As condições de produção do discurso kardecista eram apresentadas como mais objetivas e, portanto, "comprováveis" perante as exigências da sociedade brasileira do final do século XIX, extremamente influenciada pela difusão do pensamento positivista. Basta lembrar que Kardec era renomado pedagogo europeu, discípulo direto de Pestalozzi e autor de diversos livros didáticos sobre física, química, fisiologia e ortografia. Por outro lado, quem seria Zélio Fernandino de Moraes ou mesmo o Caboclo das Sete Encruzilhadas aos olhos desta sociedade? Segundo a visão geral dos kardecistas ortodoxos seriam os representantes de uma seita impura por se dedicar a um ritualismo "primitivo". Para os umbandistas, que começavam a se organizar como grupo religioso, eram espíritos de luz, seguidores da mesma Codificação, que vieram aperfeiçoá-la e humanizá-la, unindo-a a outras tradições e popularizando a mensagem

\footnotetext{
${ }^{7} \mathrm{Na}$ Codificação kardecista, o advento do Espiritismo é apresentado como a Terceira Revelação cristã que veio complementar o Decálogo mosaico (primeira) e o anúncio do Evangelho (segunda). A umbanda viria para dar continuidade a este fenômeno.
} 
evangélica.

Com relação aos conflitos com a tradição católica é fundamental conhecer a obra do Frei Boaventura Kloppenburg, bispo alemão naturalizado brasileiro que dedicou seus estudos a combater o "sincretismo" religioso. Para este, "o cerne da Umbanda não é cristão: é profunda e visceralmente contrário à autêntica vida cristã. A idolatria e as superstições do paganismo constituem a verdadeira essência do Espiritismo Umbandista" (KLOPPENBURG, 1961, p. 41).

Aqui vemos a disputa pelo espaço de cristandade e brasilidade. O Brasil foi "descoberto" e fundado sob a égide da cruz de Cristo, representado por muitos cronistas coloniais como uma terra de natureza paradisíaca e população "selvagem" que deveria ser "reedenizada" pelo processo de colonização e catequização. Este intento certamente enfrentou muitas resistências principalmente por parte das tradições indígenas, africanas ou mesmo de alguns aspectos do paganismo europeu que à sua maneira resistiram à conversão cristã ou criaram novas formas híbridas de culto que o Santo Ofício tentou reprimir. Aos olhos do colonizador, a terra exuberante do Brasil contrastava com seus habitantes "selvagens", entregues à idolatria demoníaca. Este meio termo simbólico entre natureza celeste e população "infernal" foi traduzido pelo padre Antônio da Nóbrega como purgatório: espaço de remissão e purificação dos pecados, através do trabalho árduo para o acúmulo de riquezas, junção providencial dos objetivos mercantilistas da Coroa lusa ${ }^{8}$.

Até a primeira metade do século $\mathrm{XX}$ a hegemonia da religião católica enquanto expressão religiosa dominante era indiscutível, todavia estava fragmentada em manifestações regionais expressas pelas "irmandades e confrarias" (HOORNAERT, 1977, p.384). Com o passar dos anos, a Igreja se viu obrigada a lutar por seu "espaçosímbolo" de religião nacional frente ao crescimento de outras tradições como o protestantismo, a maçonaria, o espiritismo e o comunismo (CARNEIRO, 1990). Já em 1953, a CNBB instituiu a "Secção Anti-Espírita" do Secretariado Nacional de Defesa da Fé e da Moral, uma repartição que deveria zelar pelos princípios católicos em virtude da difusão dos cultos mediúnicos, principalmente os de origem afro-brasileira.

Artur César Isaías (1998) afirma que durante a década de 50 o discurso de degradação da umbanda foi corroborado, em grande medida, pela Igreja Católica que se sentia incomodada com a associação entre a noção de brasilidade e os cultos afro-

\footnotetext{
${ }^{8}$ Vide Laura de Melo e Souza, 1986.
} 
brasileiros. A Igreja via a necessidade de reforçar seu papel como a tutora espiritual da nação brasileira, "descoberta" por um "cavaleiro da Ordem de Cristo", Pedro Álvares Cabral, e consagrada à Santa Sé no ato da primeira missa celebrada em Porto Seguro.

Ainda em 1953, a umbanda seria alvo principal de uma ferrenha campanha da CNBB contra o mediunismo, denominada "Campanha Nacional Contra a Heresia Espírita”, cujo idealizador, Frei Kloppenburg, escreveu o livro Umbanda do Brasil Orientação para católicos que denunciava o perigo das práticas umbandistas consideradas heréticas e demoníacas. Diversos costumes que atraíam católicos, como o ato de jogar flores para Iemanjá no dia 31 de dezembro, foi classificado como grave pecado de idolatria e politeísmo.

As autoridades eclesiásticas não podiam admitir o ideal de brasilidade que a intelectualidade umbandista reivindicava, bem como não conseguiam digerir a filiação destas práticas ao cristianismo, realizada ritualisticamente pela correspondência entre os santos e os orixás. Os outros cultos mediúnicos como o kardecismo e o candomblé não representavam estas ameaças, pois não disputavam os mesmos espaços simbólicos de cristandade e brasilidade ${ }^{9}$, e não possuíam o grau de popularidade que a umbanda atingiu a partir da metade do século XX.

$\mathrm{Na}$ introdução de sua obra, frei Boaventura ressalta que a impureza do culto umbandista era significada, acima de tudo, por seu aspecto híbrido, incompatível com a ideia do que seria verdadeira religião. "Não é possível ser ao mesmo tempo católico e umbandista (...) não se trata de uma posição contra a cultura africana, mas contra um movimento que (...) tem o declarado propósito de paganizar o cristianismo". (KLOPPEMBURG, 1961, p.7).

Em seu livro, frei Boaventura chega a listar dezesseis tipos de crimes cometidos por influência das práticas umbandistas, exemplificados por manchetes de jornais da época, alertando a população para os desvios supostamente realizados em nome de uma "desenfreada liberdade religiosa" que gerava um ambiente favorável ao assassinato, exploração, curandeirismo, baderna e loucura. A prática umbandista seria considerada inconstitucional, pois infringiria "a Ordem Pública e os bons Costumes" ${ }^{10}$ e deveria ser

\footnotetext{
${ }^{9}$ Pode-se afirmar que nenhuma das duas denominações tinha a preocupação de se auto representar como uma religião brasileira. Enquanto o candomblé era visto genericamente como pura feitiçaria ou "magia negra" (fato que atemorizava a maioria da população e restringia suas práticas a um pequeno grupo das camadas baixas), o kardecismo, apesar de se autodenominar uma religião cristã, não fazia referência direta aos santos, tidos como o grande fator atrativo do catolicismo popular. Além disso, o espiritismo era uma religião de forte cunho intelectual que atingia uma parcela bem mais restrita da população.

${ }^{10}$ Conforme o artigo 141 , inciso $7^{\circ}$, da Constituição de 1946: É inviolável a liberdade de consciência e de
} 
combatida pela polícia afim de "proibir ou dissolver procissões umbandistas com imagens de Santos Católicos", sendo considerada legítima "a ação coercitiva da polícia em retirar os nomes de Santos Católicos dos portais das tendas e terreiros” (Ibid., p. 132).

Boaventura conclui seu livro afirmando que a umbanda é uma religião prioritariamente de pobres e favelados que, obrigados a enfrentar situações de miséria e degradação moral, viam nela uma "religiosidade disponível". Esta concepção reforça a noção de impureza da umbanda como uma prática inculta e degenerada, difusa em meio à "sub-proletários desorientados que estão à mercê de qualquer aventura religiosa" (Ibid., p. 236).

A primeira reportagem veiculada no Jornal de Umbanda a respeito da campanha encabeçada por Boaventura chega a afirmar que a Igreja havia se transformado em uma instituição materialista, comparada aos governos ditatoriais como "um movimento político internacional com finalidades idênticas ao comunismo", que visa conquistar "a maior quantidade possível de dinheiro e ouro das nações onde impõe a sua doutrina retrógrada e fascista, para enviá-los a seu quartel general, o Vaticano, em Roma" ${ }^{11}$.

A reação dos umbandistas foi de crítica, mas também de adaptação. Eles desejavam o respeito da Igreja e da sociedade, mas sabiam que para isso era preciso deixar claro a moralidade e "civilidade" de seu culto. É interessante notar a preocupação com o patrulhamento das cerimônias públicas de umbanda muito frequentes nos finais de ano:

Precavenham-se dos prevaricadores e falsos umbandistas que por ignorância, má fé ou exibicionismo (...) portam-se em praias mais que profanas a dançarem vestidos de exus, com paramentos pretos e vermelhos, tridentes e garrafas de cachaça a promoverem matança de galinhas ou outros animais quaisquer a pretexto de estarem cultuando nossa mãe Iemanjá na despedida do ano ${ }^{12}$.

\section{O Puro e o Híbrido: Especificidades da Umbanda Pura}

Tanto quanto o Budismo aproveitou quase tudo do Bramanismo, o Cristianismo conservou o melhor do Mosaísmo, assim a Umbanda aproveita, conserva e guarda o que de bom e aproveitável pode haver

crença e assegurado o livre exercício dos cultos religiosos, salvo o dos que contrariem a ordem pública ou os bons costumes (...).

${ }^{11}$ Jornal de Umbanda. № 53, Abril de 1955, p. 10.

${ }^{12}$ Jornal de Umbanda. № 85, Dezembro de 1958, p. 01. 
em todas as religiões do passado. A Umbanda não é apenas uma corrente religiosa: ela é o sincretismo de todas as correntes, ela guarda os fundamentos de todas as teogonias e resume as bases de todas as filosofias ${ }^{13}$.

O ideal de pureza almejado pela Umbanda Pura, ao contrário das pretensões primordialmente essencialistas das tradições que a inspiraram, se constrói dentro da perspectiva plural e misturada. O ecletismo do culto umbandista é constitutivo de sua própria identidade, calcada na mistura de elementos de tradições religiosas distintas. No discurso dos intelectuais umbandistas, o caráter assimilativo da Umbanda está associado ao progresso e à supremacia espiritual pelo acúmulo de várias referências religiosas. A moralidade cristã é a base desta mescla que permite a influência de várias tradições, desde que estas se submetam a certa visão positiva e reencarnacionista e evolucionista do cristianismo.

\begin{abstract}
A Umbanda no Brasil precedeu o Kardecismo, contudo assimilou-o, logo que ele apareceu (...) expondo, também, de forma magnífica, a parte eterna dos Evangelhos de Jesus Cristo, que é a sua moral. (...) A Umbanda não combate as outras religiões, mas assimila os novos conhecimentos que elas tragam, para o bem da humanidade (...). A umbanda é uma coletividade de espíritos hierarquizados e divididos em linhas ou padrões de vibrações (...) é um movimento religioso, evolutivo, assimilativo de tudo o que é bom para o progresso humano14.
\end{abstract}

Apesar deste estudo se ater ao conceito de hibridismo (CANCLINI, 2001), percebe-se a pertinência de explicitar as definições de sincretismo e de síntese utilizadas por estudos consagrados sobre a umbanda com o intuito de esclarecer a pluralidade do culto. Lísia Negrão (1996) aborda o sincretismo como um sistema que combina diversos elementos, mas permite a manutenção das diferenças, pois “esta é a razão da identidade da umbanda, formada no bojo do processo sincrético, apresentar-se de forma múltipla e variável no tempo (...) sincretismo é um processo, um contínuo fazer e refazer, não um estado, um produto final" (NEGRÃO, 1996, p. 38).

Segundo Renato Ortiz (1980) a umbanda seria uma síntese por articular vários elementos que, ao se misturarem, geram algo novo. As diversas tradições formadoras da umbanda estariam diluídas e homogeneizadas. É Provável que os articuladores da "Umbanda Pura" buscassem uma explicação mais próxima à síntese globalizante

\footnotetext{
${ }^{13}$ Emanuel Zespo. Codificação da Lei de Umbanda. Rio de Janeiro: Parte Científica, 1951, p. 08.

${ }^{14}$ Jornal de Umbanda. $\mathrm{N}^{\mathrm{o}} 72$, Setembro de 1957, p. 06.
} 
teorizada por Ortiz, pois desejavam ser aceitos como autênticos praticantes de uma religião nova e independente, portanto pura e verdadeira.

\begin{abstract}
À princípio muito ligada às religiões de que se serviu para seu desenvolvimento, vai aos poucos constituindo-se em religião independente, abandonando, aos poucos, os santos que tomou por empréstimo ao teogonismo católico e esquecendo-se das formas fetichistas africanas (...) explicando-se, assim, pela ciência espiritual pura (...). Sem doutrina fixa escrita, por isso mesmo tende a amoldarse, absorvendo, ecleticamente, de outras religiões, o que elas têm de verdade $^{15}$.
\end{abstract}

Todavia, ao analisarmos o cotidiano das tendas, esta homogeneização está longe de ser encontrada. Cada terreiro revela maior ou menor afinidade com os elementos religiosos formadores, refletindo a discrepância entre o projeto federativo e prática religiosa. Os processos de hibridização descartam quaisquer pretensões de hegemonia dos purismos ou autenticidades bem como das identidades locais isoladas. Ou seja, apesar de serem concebidos como "processos socioculturais nos quais as estruturas ou práticas discretas, que existiam de forma separada, se combinam para gerar novas estruturas, objetos e práticas" (CANCLINI, Op. Cit., p. 14), assim não articulam a ideia de uma mistura homogênea, estática, fixa. Seu ritual está mais próximo da perspectiva da hibridização pela circulação de sentidos múltiplos que ali se realiza.

Interpretando as reflexões de Peter Fry, Maria Laura Viveiros de Castro alerta para a dificuldade de se entender a singularidade da umbanda se analisada em contraposição ao candomblé. Enquanto o candomblé é visto como a alteridade exótica, os signos da macumba/umbanda anuviam o olhar do pesquisador que tem dificuldade de vislumbrar as representações do "outro" devido a sua familiaridade de carga negativa, à proximidade com o cotidiano do "feitiço, da sexualidade solta, do jeitinho e do favor" ${ }^{16}$. A pluralidade do campo umbandista encontra-se na estrutura do próprio ritual que é dividido em duas grandes vertentes vibratórias: a linha da "direita" e da "esquerda". À esquerda corresponderia o culto aos Exus e Pomba-giras identificados como energias mais densas e materiais. Estas entidades teriam advindo da antiga macumba carioca e foram adaptadas, através do chamado batismo, para desfazer trabalhos pesados e auxiliar nas questões telúricas. O batismo seria um processo de doutrinação e purificação que tornaria estas entidades consideradas maléficas em guias educados e

\footnotetext{
${ }^{15}$ Jornal de Umbanda. No 44, Julho 1954.

${ }^{16}$ Peter Fry. "Gallusafricanus est, ou, como Roger Bastide se tornou africano no Brasil". Folhetim, 15 de Julho de 1984 Apud Maria Laura Viveiros de Castro Cavalcanti (1986, p.100).
} 
aptos para participar do ritual umbandista.

... o Exu pagão é tido como o marginal da espiritualidade, sem luz, sem conhecimento da evolução, trabalhando na magia do mal para o mal, em pleno reino de quimbanda (...) Já o Exu-batizado, caracteristicamente definido como alma humana sensibilizada pelo Bem, palmilhando um caminho de evolução, trabalha para o Bem, dentro do reino de quimbanda, por ser força que ainda se ajusta ao meio, nele podendo intervir, como um policial que penetra nos antros da marginalidade ${ }^{17}$.

O culto a entidades não batizadas, ou seja, aos espíritos pagãos em suas formas originais veneradas na macumba, recebeu o nome de quimbanda. É interessante perceber como a umbanda, apesar de sofrer inúmeros ataques, não conseguiu fugir do sistema valorativo da contra-estigmatização e acabou por eleger a quimbanda como um dos alvos principais de suas críticas. Para os adeptos da Umbanda Pura, a quimbanda seria uma variação do ritual umbandista voltada para prática do mal, a chamada "magia negra" ${ }^{18}$. Neste sentido, o vínculo entre umbanda e quimbanda parece indissociável como a própria polaridade bem-mal, dicotomia muito característica na tradição cristã. A quimbanda é necessária à Umbanda? Se não houvesse a "quimbanda" a Umbanda perderia seus objetivos? Seguindo esta lógica, a razão de ser da umbanda seria curar os malefícios produzidos pela quimbanda e promover a evolução dos seres que vivem na inferioridade da terra ${ }^{19}$.

Este trecho explicita como identidade e diferença são relacionais e, portanto, complementares. Os estudos culturais chamam a atenção sobre o quanto a identidade necessita da diferença para se afirmar como tal. É a distinção entre o "nós" e o "outro" que permite a construção de sistemas classificatórios que dão sentido e ordem ao mundo social, representado simbolicamente através dos discursos e dos ritos. Segundo Woodward (2000, p. 65) “é a linguagem e o simbólico que passam a fornecer alguma compensação, ao proporcionar pontos de apoio linguísticos nos quais se torna possível ancorar a identidade".

Tomaz Tadeu da Silva (1998) ressalta que a questão da linguagem é central na

\footnotetext{
${ }^{17}$ Cavalcanti Bandeira. O que é umbanda Apud Renato Ortiz, Op. cit., p. 125.

18 A quimbanda também pode ser vista como um aspecto do ritual umbandista. Algumas tendas classificam a quimbanda como a parte da umbanda que corresponde à linha da esquerda (Exus e Pombagiras) e não como uma religião à parte a ser combatida. Esta linha deveria ser controlada e contida pela hierarquia dos espíritos "da direita", mas teria um papel fundamental e indispensável na condução dos rituais de vibração mais densa, material. De qualquer maneira, a quimbanda é quase sempre temida e vista com ressalvas por lidar com forças ditas inferiores.

${ }^{19}$ Jornal de Umbanda. № 40, Março de 1954.
} 
construção do processo identitário. Os atos de linguagem criam, nomeiam, instituem, significam, definem, descrevem, qualificam, afirmando o que "é” e o que "não é" para estabelecer a diferença. Todavia a linguagem é vacilante, ambígua, devido ao aspecto representacional do signo como um sinal, um traço do "real", uma atribuição de sentido, e não a presença do "real" propriamente dita. O discurso (seja ele escrito, falado ou imagético) é a peça chave da representação social como um sistema de significação cultural fluido, inconstante, diretamente ligado às relações de poder. Ao afirmar que o objetivo da Umbanda é "destruir os maleficios produzidos pela quimbanda", os teóricos da Umbanda Pura estabelecem um juízo de valor, um lugar de autoridade em relação à quimbanda, pois "quem tem o poder de representar, tem o poder de definir e determinar a identidade (...). Questionar a identidade e a diferença significa, nesse contexto, questionar os sistemas de representação que lhe dão suporte e sustentação" (SILVA, Op. Cit., p. 91).

Outra questão que reforça o aspecto híbrido da umbanda é a variedade de seu panteão, herdada da religiosidade africana. Segundo Muniz Sodré "as tradições africanas também deixaram como legado para a umbanda a concepção da existência plural de Deus intrinsecamente ligada à existência do próprio homem” (Op. Cit., p. 174). A partir desta análise, pode-se compreender melhor o culto às chamadas forças intermediárias, representadas pelos guias e entidades que seriam manifestações específicas do Todo (Deus ou Cosmos). Esta perspectiva também pode derivar da influência direta do catolicismo popular no qual os santos são vistos como um ponto de intercessão entre o sagrado e o profano e recebem formas de veneração tão particulares que "muitas vezes ofusca o próprio criador do mundo" (ORTIZ, Op. Cit., p. 72).

Pode-se inferir que a própria afirmação da identidade plural da Umbanda Pura é um movimento de interdiscurso por basearem-se no "já-dito", nos saberes estabelecidos por outras tradições, recorrendo à memória das religiões que a constituíram para dar sentido a sua existência.

A questão que se apresenta entre Umbanda e Espiritismo é análoga a esta outra: Umbanda - Quimbanda e Candomblé (e outras linhas menos conhecidas). Assim os espiritistas lutam para estabelecer a diferença existente entre Umbanda e Espiritismo e vice-versa, os Umbandistas lutam igualmente para estabelecer a diferença entre Umbanda, a Quimbanda e o Candomblée ${ }^{20}$.

\footnotetext{
${ }^{20}$ Jornal de Umbanda. $\mathrm{N}^{\circ}$ 29, Março de 1953.
} 
O fenômeno da estigmatização como afirmação identitária também aparece no relacionamento das religiões protestantes com a umbanda. A vertente do protestantismo denominado neopentecostal desenvolveu um vínculo de proximidade e conflito com as religiões afro-brasileiras em geral. Esta corrente intensificou a magicidade do ritual pentecostal (BENEDITO, 2003) que já possuía algumas características sacrais devido à exaltação à experiência do Espírito Santo, como um bálsamo de graça e carisma sobre a rigidez ética e anti-ritual do protestantismo tradicional. $\mathrm{O}$ culto neopentecostal ${ }^{21}$ se caracteriza por dar um papel de destaque para as manifestações dos dons do Espírito Santo como profetizar, promover curas milagrosas, orar em línguas e exorcizar espíritos.

Nesta perspectiva, Jesus teria concedido, a cada pastor e a cada fiel converso, capacidade de desenvolver poderes sobrenaturais para lutar contra as forças do mal, difundidas no seio da sociedade. Curiosamente, a exemplificação das ações do mal ou do demônio, na doutrina da maioria das denominações neopentecostais desenvolvidas no Brasil, são diretamente associadas aos cultos afro-brasileiros. Na verdade, pode-se entender o processo de estigmatização do culto umbandista como elemento constitutivo da própria identidade de várias vertentes neopentecostais (BARROS, Op. Cit., p. 115) como a Igreja Universal do Reino de Deus, Igreja Renascer em Cristo e Igreja Internacional da Graça de Deus. Um dos principais pontos do ritual destas denominações é o de desfazer "amarrações", magias, feitiços, macumbas e livrar as pessoas dos "encostos", os chamados espíritos maléficos que impõem entraves e contendas, através de exorcismos e sessões de descarrego. Ora, esta também seria uma função da Umbanda Pura se comparada à quimbanda e outras denominações que pratiquem a magia anômica. Além disso, a questão da melhoria da vida material e cotidiana, do foco no tempo presente, é uma preocupação tanto da Umbanda como destas denominações que baseiam suas ações na Teologia da Prosperidade e da Batalha Espiritual $^{22}$.

\footnotetext{
${ }^{21} \mathrm{O}$ neopentencostalismo seria uma radicalização dos princípios pentecostais, baseando seu culto na batalha espiritual contra as forças demoníacas. Foi introduzido no Brasil com a fundação da Igreja Universal do Reino de Deus em 1977.

${ }^{22}$ Herança da colonização puritana, a Teologia da Prosperidade é originária dos Estados Unidos e se difundiu no período pós-crise de 29. Prega o sucesso financeiro e social pelo poder da fé, por meio da confissão positiva ou autoafirmação das bênçãos de Deus (promessa de vida abundante e isenta de problemas, caracterizada pela pregação das "determinações das vitórias" em voz alta). Esta abordagem baseia-se na guerra espiritual contra o poder de Satanás, fonte de toda provação e sofrimento. Nesta perspectiva, não há espaço para aceitar as vicissitudes da vida como as enfermidades, as dificuldades financeiras ou problemas sentimentais, pois tudo isto é visto como obra do demônio que deve ser
} 
$\mathrm{O}$ embate entre neopentecostais e afro-brasileiros não se resume apenas à tentativa de afirmação de uma identidade religiosa, mas também à disputa de um mercado de bens e serviços simbólicos (...) os neopentecostais vêm cada vez mais dirigindo seus ataques à resolução de problemas materiais de seus fiéis, fazendo com que a felicidade espiritual subordine-se à material (BENEDITO, Op. Cit., p. $80)$.

O discurso neopentecostal de demonização dos cultos afro-brasileiros como justificativa para combater veementemente a "magia negra" vem acompanhado de certas práticas rituais muito semelhantes às da umbanda e do candomblé, como o "descarrego espiritual" pelo uso do sal, óleos bentos, galhos de arruda para afastar "mau-olhado", indução à possessão, expulsão de espíritos, quebra de maldições e, no caso da Igreja Universal, até oferta de balas e doces no dia de Cosme e Damião e utilização de fitas protetoras, semelhantes à fita do Senhor do Bonfim (FRANCISCO, 2004). Um dos maiores sucessos editoriais do gênero neopentecostal é o livro Orixás, Caboclos e Guias: deuses ou demônios? escrito pelo ex-umbandista Edir Macedo, bispo fundador da Igreja Universal do Reino de Deus. Editado em 1980, o livro é um Best seller e seu conteúdo deprecia abertamente a imagem dos cultos afro-brasileiros e do espiritismo, em geral vistos como abominação e demonolatria, principais geradores de todo tipo de malefícios. Interessante perceber, no entanto, que as "técnicas" recomendadas para livrar-se da influência de Satanás são semelhantes aos trabalhos de limpeza da Umbanda que, todavia, levam nomes diferentes: saravá, despacho é chamado de descarrego ou exorcismo na IURD; os guias ou entidades são designadas como "encostos" pelo pastor; o passe corresponderia às correntes de oração de imposição de mãos; a incorporação é chamada de possessão demoníaca, etc.

Se alguém chegar à igreja no momento em que as pessoas estão sendo libertas, poderá até pensar que está em um centro de macumba, e parece mesmo (...) quando fazemos a limpeza em suas vidas, quando os demônios são expelidos levam com eles todo o mal, aí vem a bonança (...). Nessas reuniões milhares de pessoas tem se libertado dos exus, caboclos, orixás, erês e outros demônios (MACEDO, 2004, p. 23).

Todos estes processos de troca discursiva ainda forjam a identidade da Umbanda Pura que se constituiu e se constitui...

combatido. Cf Etiane Caloy Bovkalovski de Souza. "Os pentecostais: entre a fé e a política" in Revista Brasileira de História. São Paulo: Vol. 22, nº 43, 2002. 
... inserida num ambiente cósmico dividido entre diversas facções que se relacionam por meio de ataques e defesas místicas. Como ocorre nas disputas de amor e noutras situações competitivas: o bem de uma parte pode ser o mal de outra, e vice-versa (BARROS, Op. Cit., p. 6).

Ela é retaliada justamente por reunir elementos de diversas tradições em torno de uma mensagem cristã, de um ritual mágico didático e moralizante, de uma sabedoria letrada, de ações voltadas para os problemas cotidianos e, principalmente, de signos que a aproximam de uma ideia do que é ser brasileiro. A representação da brasilidade na Umbanda incomoda e fascina, pois tenta congregar o marginal e o intelectual, a transgressão e a moral, a magia e a religião. A identidade da umbanda é escorregadia, complexa, plural, como a identidade da própria nação brasileira.

\section{Referências Bibliográficas}

ALCÂNTARA, Alfredo. Umbanda em Julgamento. Rio de Janeiro: Gráfica Mundo Espírita, 1949.

BANDEIRA, Antônio Cavalcanti. Umbanda: evolução histórico-religiosa. Rio, 1961.

BARROS, Sulivan Charles. Brasil Imaginário: Umbanda, Poder, Marginalidade Social e Possessão. Tese de Doutorado apresentada ao Programa de Pós-Graduação em Sociologia da Universidade de Brasília. Brasília: UnB, 2004.

BASTIDE, Roger. As Religiões Africanas no Brasil. São Paulo: Pioneira, 1989.

Estudos Afro-Brasileiros. São Paulo: Perspectiva [Estudos 18], 1973.

BENEDITO, Júlio Cézar. EmiPadê! Magia, Conflito religioso e simbiose ritualística no Brasil contemporâneo. Tese de Doutorado apresentada ao Programa de Pós-Graduação em Sociologia da Universidade de Brasília, 2003.

BIRMAN, Patrícia. O que é Umbanda. Brasiliense, 1983.

. "Registrado em Cartório com firma reconhecida: as mediações políticas das federações de umbanda" In Umbanda e Política. Cadernos do ISER, no 18 . Rio de janeiro: Marco Zero/ISER, 1985, p.80-156. 
BOURDIEU, Pierre. "Gênese e estrutura do campo religioso" in A Economia das Trocas Simbólicas. São Paulo: Perspectiva, 1992, p. 46.

A economia das trocas linguísticas. $2^{\text {a }}$ ed., São Paulo: Edusp, 1998.

BRITTO, Cristina da Silva. Umbanda, Ordem e Progresso: a representações das origens, construção identitária e institucionalização da "umbanda pura" no Rio de Janeiro (1908-1961). Dissertação (mestrado) apresentada ao Programa de PósGraduação de História da Universidade de Brasília, 2005.

BROWN, Diana. "Uma história da Umbanda no Rio" in Umbanda e Política. Cadernos ISER, nº 18. Rio de Janeiro: Marco Zero/ ISER, 1985.

CAMARGO, Cândido Procópio Ferreira de. Kardecismo e Umbanda. São Paulo, Pioneira, 1961.

CANCLINI, Nestor Garcia. Culturas Híbridas: Estrategias para entrar y salir de la modernidad. Buenos Aires: Editorial Paidós, 2001.

CARNEIRO, M. Luiza Tucci. "Sob a máscara do nacionalismo: Autoritarismo e Antisemitismo na Era Vargas (1930-1945)". Revista virtual de Estudios Interdisciplinares de América y El Caribe-EIAL. Volumen 1, n. 1, Enero de 1990. TelAvivUniversity.

CAVALCANTI, Maria Laura Viveiros de Castro O Mundo Invisível: cosmologia, sistema ritual e noção de pessoa no espiritismo. Rio de Janeiro: Zahar Editores, 1983. "Origens para que as quero? Questões para uma investigação sobre a Umbanda” in Religião e Sociedade, n 13/2, julho, 1986.

CHAUÍ, Marilena. Brasil: Mito fundador e sociedade autoritária. São Paulo: Fundação Perseu Abramo, 2000.

CONCONE, Maria Helena Villa Boas. Umbanda: Uma Religião Brasileira. São Paulo: CER-FFLCH/USP, 1984.

DAMAZIO, Sylvia. Da Elite ao povo - Advento e expansão do Espiritismo no Rio de Janeiro. Rio de Janeiro: Bertrand do Brasil, 1994.

DANTAS, Beatriz Góis. Vovô nagô e pai branco. Rio de Janeiro: Graal, 1988. . Repensando a pureza nagô. Religião e Sociedade, $n^{\circ}$ 08,1982.

DOUGLAS, Mary. Pureza e Perigo. São Paulo: Perspectiva, 1996.

ELIAS, Norbert e SCOTSON, John L. Os Estabelecidos e os Outsiders: sociologia das relações de poder a partir de uma pequena comunidade. Rio de Janeiro: Jorge Zahar Editor, 2000.

FONTENELLE, Aluízio. A Umbanda através dos séculos. Rio de Janeiro: Organizações Simões, 1953. O Espiritismo no conceito das religiões e a Lei de Umbanda. Rio de Janeiro: Editora Aurora, s/d. 
FRANCISCO, Adilson José. "História e religiosidade: ressignificação contemporânea da tradição afro-brasileira" in Revista Virtual Historicidade, UNIVAS, 2004.

FRY, Peter. Duas Respostas à aflição: umbanda e pentencostalismo. Debate e Crítica, $\mathrm{n}^{\circ} 06,1975$. Pra inglês ver. Rio de Janeiro: Jorge Zahar, 1982.

GIUMBELLI, Emmerson. O Cuidado dos mortos - uma historia da condenação e legitimação do espiritismo. Rio de Janeiro: Arquivo Nacional, 1997.

. "Zélio de Morais e as origens da Umbanda no Rio de Janeiro" In: Candomblé

$\bar{e}$ Umbanda-Caminhos da devoção brasileira. São Paulo: Ática, 1994.

HALL, Stuart. A identidade cultural na pós-modernidade. Rio de Janeiro: DP\&A Editora, 2002.

HOORNAERT, Eduardo (coord.). História da Igreja no Brasil - Primeira Época. Petrópolis: Vozes, 1977.

ISAIA, Artur César. O Elogio ao Progresso na obra dos Intelectuais da Umbanda. Anais do $6^{\circ}$ Congresso da Associação Internacional de Lusitanistas. Lisboa, 1999 in http://members.tripod.com/bmgil

- "Huxley sobe o Morro e desce ao Inferno - A Umbanda no discurso católico dos anos 50". Revista Imaginário, n 04, NIME/LABI/USP, 1998.

"A Umbanda: imagens do inimigo no discurso católico de meados do século XX". Artigo virtual apresentado no site da Associação Brasileira de História das Religiões-ABHR inhttp://members.tripod.com/bmgil/

(115),1997.

Umbanda e Nacionalismo no Brasil. Teocomunicação, $\mathrm{n}^{\circ} 27$

JODELET, Denise. As Representações Sociais. Rio de Janeiro: EdUERJ, 2001.

JORNAL DE UMBANDA. Órgão Noticioso e Doutrinário da União Espiritista de Umbanda do Brasil. Rio de Janeiro: março de 1952 a dezembro de 1960. Acervo da Biblioteca Nacional do Rio de Janeiro -Ano II-X (Ns. 16,27-104).

KARDEC, Allan. Evangelho Segundo o Espiritismo. Araras: Instituto de Difusão Espírita, 2001.

KLOPPENBURG, Boaventura. A Umbanda no Brasil. Petrópolis: Vozes, 1961.

MACEDO, Edir. Orixás, Caboclos e Guias: deuses ou demônios?. Rio de Janeiro: Gráfica Editora Universal, 2004.

MAGNO, Oliveira. Umbanda e Ocultismo. Rio de Janeiro: Ed. Espiritualista, 1952.

MARTINS, Maurício. "Reencantamento do Mundo". Entrevista concedida pelo autor à Revista Época, Coluna Sociedade, Edição 367, de 30 de maio de 2005.

MONTEIRO, Douglas Teixeira. "Roger Bastide: Religião e Ideologia" in Religião e 
Sociedade. Rio: Civilização Brasileira, 1978.

NEGRÃO, Lísias Nogueira. Entre a Cruz e a Encruzilhada. São Paulo: Edusp, 1996. OLIVEIRA, Jota Alves de. Evangelho na Umbanda: Livro doutrinário baseado em observações, estudos e práticas de Umbanda, interpretados à luz do Evangelho de Jesus. Rio de Janeiro: Tecnoprint, 1987.

Umbanda cristã e brasileira. Rio de Janeiro: Ediouro, 1985.

ORTIZ, Renato. A Consciência Fragmentada: Ensaios de Cultura Popular e Religião. Rio de Janeiro/São Paulo: Paz e Terra, 1980. . A Morte Branca do Feiticeiro Negro. Petrópolis, Vozes, 1978.

"Breve Nota sobre a Umbanda e suas origens" in. Religião e Sociedade, no 13/1. Petrópolis, Vozes, 1986. . Cultura Brasileira e Identidade Nacional. São Paulo: Brasiliense, 1994.

PRANDI, Reginaldo. A Realidade social das religiões no Brasil-Religião, sociedade e política. São Paulo: Hucitec, 1996. Encantaria Brasileira. Rio de Janeiro: Pallas, 2001.

RAMOS, Arthur. O Negro Brasileiro. Rio de Janeiro: Grafia, 2001.

Brasil, 1971. . O Negro na Civilização Brasileira. Rio de Janeiro: Casa do Estudante do

RODRIGUES, Nina. Animismo fetichista dos negros baianos. Rio de Janeiro: Civilização Brasileira, 1935.

RUANDA, Adib. Catecismo de Umbanda (Lex Umbanda). Rio de Janeiro: Ed. Espiritualista, 1975.

SERRA, Ordep. Dois Estudos Afro-brasileiros. Salvador: Centro Editorial da UFBA, 1996.

SILVA, Tomaz Tadeu da (org.). Identidade e diferença: a perspectiva dos estudos culturais. Petrópolis: Vozes, 1998.

SILVA, Vagner Gonçalves da. Caminhos da Alma: Memória Afro-brasileira. São Paulo: Summus,2002.

SKIDMORE, Thomas. Preto no Branco: raça e nacionalidade no pensamento brasileiro. Rio de janeiro: Paz e Terra, 1976.

SODRÉ, Muniz. Claros e Escuros: identidade, povo e mídia no Brasil. Petrópolis: Vozes, 1999.

SOUZA, Laura de Melo e. O Diabo e a Terra de Santa Cruz - feitiçaria e religiosidade popular no Brasil colonial. São Paulo: Cia das Letras, 1986.

SOUZA, Leal de Souza. O espiritismo, a magia e as sete linhas da Umbanda. Rio de Janeiro, s/e, 1933. 
Revista Calundu - Vol.3, N.1, Jan-Jun 2019

TEIXEIRA, Antônio Alves. Umbandismo. Rio de Janeiro: Gráfica Editora Aurora, 1957.

TRINDADE, Diamantino Fernandes. A Umbanda e sua História. São Paulo: Ícone, 1991.

TRINDADE, Liana Maria Sálvia. "Umbanda - a ideologização do Mítico" in VIII Encontro Anual da ANPOCS (mimeo), 1984.

ZESPO, Emanuel. Codificação da Lei de Umbanda. Rio de Janeiro: Parte Científica, 1951.

WEBER, Max. "Tipos de Comunidade religiosa (Sociologia da Religião)" in Economia e Sociedade. Brasília: EdUnB, 1994.

WOODWARD, Kathryn. "Identidade e diferença: uma introdução teórica e conceitual" in SILVA, Tomaz Tadeu (org.). Identidade e Diferença: A perspectiva dos Estudos Culturais. Petrópolis: Vozes, 2000.

Recebido em: 05/05/2019

Aceito em: 13/05/2019 